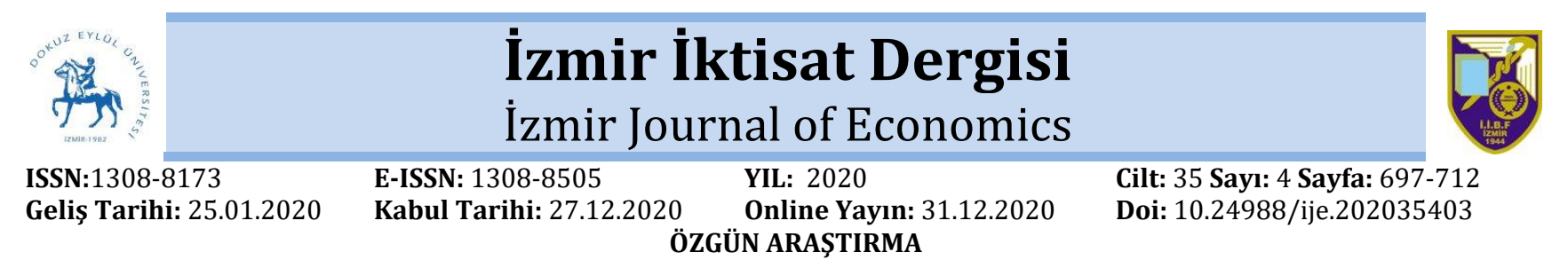

\title{
Makroekonomik Kırılganlık ve Ekonomik Büyüme Arasında Nedensellik İlişkisi: Çin Örneği
}

\section{Mustafa BAYLAN 1}

Özet

\begin{abstract}
Ekonomik kırılganlık mikro ve makroekonomik açıdan ele alınmaktadır. Mikroekonomik perspektif șokların bireysel hane halklarının refahı üzerindeki etkisiyle ilgilenirken, makroekonomik perspektif ise bu şokların ekonomik büyüme üzerindeki etkisine odaklanmaktadır. Bu çalışmanın amacı makroekonomik kırlganlık ile ekonomik büyüme arasındaki ilişkiyi incelemektir. Bu yazıda 1987-2018 dönemini kapsayan yıllık veriler kullanılarak Çin örneğinde makroekonomik kırılganlık ile ekonomik büyüme arasında nedensellik ilișkisini ortaya koymak için Johansen eșbütünleșme ve Granger nedensellik testleri kullanılmıștır. Analizlerden üç önemli sonuç elde edilmiştir. Birincisi, Çin'in makroekonomik kırılganlığı 2011'den beri artmaktadır; Íkincisi, makroekonomik kırılganlık ile büyüme arasında uzun dönem ilişki mevcuttur; Üçüncüsü, ekonomik büyüme ile makroekonomik kırılganlık arasında çift yönlü bir nedensellik ilişsisi vardır.
\end{abstract}

Anahtar kelimeler: Makroekonomik Kırllganlık, Ekonomik Büyüme, Nedensellik Analizi, Çin Jel Kodu: C8, E6, F4, N1, 04

The Relationship Between Macroeconomic Vulnerability And Economic Growth:

The Case Of China

\begin{abstract}
Economic vulnerability is handled from micro- and macroeconomic perspectives. While the microeconomic perspective is concerned with the impact of shocks on the well-being of individual households, the macroeconomic perspective focuses on the impact of these shocks on economic growth. The aim of this study is to investigate the relationship between macroeconomic vulnerability and economic growth. In this paper, Johansen cointegration and Granger causality tests are applied to examine the causal relationship between macroeconomic vulnerability and economic growth for a sample of China by using annual data covering the period 1987-2018. Three important results were obtained from the analyzes. First, China's macroeconomic vulnerability has increased since 2011; Second, macroeconomic vulnerability and economic growth have a long run relationship; Third, there is a bidirectional causality relationship between economic growth and macroeconomic vulnerability.
\end{abstract}

Keywords: Macroeconomic Vulnerability, Economic Growth, Causality Tests, China

Jel Codes: C8, E6, F4, N1, O4

\section{GíRiş}

Kirılganlık kavramı iktisat yazınında 1960'lardan beri yer almasına rağmen (Minsky, 1966) ortak bir tanımına rastlamak mümkün değildir. İktisat literatüründe karşılaşlan ilk tanımlardan biri Minsky (1976:8)'a aittir. O'na göre ekonomik kırılganlık bir ekonominin yükümlülüklerini yerine getirirken ortaya çıkan küçük bazı aksamalardan dolayı zincirleme büyük değişmeler yaşaması ve ekonominin kendini toparlayamamasıdır. Diğer bir tanıma göre ise kırılganlık, bir ekonominin normal değişkenlik aralığının ötesine geçen bir tür bozulma veya ani "şoktan" olumsuz etkilenmesidir (Essers, 2015:22).

Ekonomik kırılganlığı mikro ve makroekonomik kırılganlık olarak tasnif etmek mümkündür. Mikroekonomik kırılganlık negatif şokların hane halkı refahı üzerindeki,

ATIF ÖNERISİ (APA): Baylan, Mustafa. (2020). Makroekonomik Kırılganlık ve Ekonomik Büyüme Arasında Nedensellik İlişkisi: Çin Örneği. İzmir İktisat Dergisi. 35(4). 697-712. Doi: 10.24988/ije.202035403

1 Dr. Öğr. Üyesi, Kahramanmaraş Sütçü İmam Üniversitesi, İktisadi ve İdari Bilimler Fakültesi, Onikişubat/ Kahramanmaraș, EMAIL: m_baylan@ksu.edu.tr ORCID:0000-0001-8604-4634 


\section{BAYLAN}

makroekonomik kırılganlık ise bu şokların büyüme üzerindeki etkisini konu edinmektedir. Yani, mikroekonomik kırlganlık bir ailenin yoksulluğunun devam edip etmeyeceği veya gelecekte hane halkı gelirinin yoksulluk sınırının altına düşüp düşmeyeceği; makroekonomik kırılganlık ise bir ülkedeki ekonomik büyümenin ne olacağı ile ilgilenmektedir (Seth ve Ragab, 2012:1). Böyle bir tasnif literatüre girmiş olmasına rağmen mikro ve makroekonomik kırılganlıkları birbirlerinden ayrı düşünmek hemen hemen imkânsız olarak kabul edilmektedir.

Makroekonomik kırılganlık bir ülkenin yapısı ve özellikleri nedeniyle ortaya çıkabildiği gibi, uygulanan politikalara bağlı olarak ta ortaya çıkabilmektedir. Ülkenin yapısı ve özellikleri nedeniyle ortaya çıkan kırılganlığa "yapısal kırılganlık" denilmekte ve hemen değişmemekte, kalıcı unsurlar içermektedir. Mevcut politika tercihlerinden kaynaklanan kırılganlığa ise "genel kırılganlık" denilmekte, bu özelliğinden dolayı daha hızlı değişmektedir (Guillaumont 2017: 7).

Makroekonomik kırılganlık farklı bileşenlerden oluşmakta ancak bunların neler olduğu hususunda ortak bir görüş bulunmamaktadır (Brugliglo, 1997; Atkins vd., 2000; Wells ,1997;IMF, 2008; FED, 2014; Dabla-Norris ve Gündüz, 2014; Dalhaus ve Lam, 2018). Buna rağmen, dış kırılganlık, mali kırılganlık ve finansal kırılganlı makroekonomik kırılganlığın ana bileșenleri olarak kabul görmektedir. Dış kırılganlık, yabancı yatırımcıların yatırım yapmak için getirdikleri sermayeyi, vade sonunda getirisiyle birlikte geri alıp alamayacakları açısından önem arz etmektedir. Dış kırılganlığın tespitinde cari açık, uluslararası döviz rezervleri, reel kur ve toplam dış borç önemli rol oynamaktadır. Mali kırılganlık ise devlet bütçesinin durumu hakkında bilgi vermektedir. Dış açıkla birleşmesi halinde "ikiz açık" sorunu ortaya çıkacak ve kırılganlık derinleșecektir. Mali kırılganlığın tespitinde bütçe açığı ve toplam kamu borcu iki ana büyüklüktür. Finansal yapının sağlamlığını merkeze alan ise finansal kırılganlıktır. Yani, finansal sistemin kırılganlığı üretim ve satıştan elde edilen gelirlerin, üretim ve satış için yüklenilen borçların geri ödemesine yetip yetmemesine bağlıdır. $\mathrm{Bu}$ çerçevede, eğer finansal sistem içerisinde gelirler yükümlülüklerin yerine getirilmesi için yeterli değilse, sistemdeki kırılganlıkların arttığı söylenebilir. Finansal kırılganlık toplam mevduat, toplam kredi, kredi büyüme oranı ve finansal sektörün yabancı bankalar borcundan etkilenmektedir (Özylldız, 2014).

Birçok faktör makroekonomik kırılganlığı etkileyebilmektedir. Ekonomik açıklık, tasarruf açığı, düşük rezerv oranı ve zayıf ulusal para bunlar arasında yer almaktadır. Ekonomik liberalizasyon ekonomik kırılganlığı etkileyen önemli unsurdan biri olarak görülmektedir. Ekonomik açıklık, bir ülkenin diğer ülkelerin ekonomik koşullarına ne derece duyarlı olduğunu göstermektedir. Ekonomik açıklık olumlu gelişmeler yaratmakla birlikte, özellikle gelişmekte olan ülkelerde olumsuz sonuçlar da yaratmaktadır. Özellikle sürekli cari açıklara, cari açıkların kısa vadeli sermaye ile finanse edilmesine, portföy yatırımlarının ülkeye hızlıca girmesine ve çıkmasına ve nihai olarak kırılganlığın artmasına neden olmaktadır. Öyle ki kısa vadeli sermaye hareketleri 1994 Meksika Krizi, 1997 Asya Krizi, 1998 Brezilya Krizi ve 2001 Türkiye Krizlerinin nedeni olarak kabul edilmektedir (Örnek, 2008:201).

Tasarruf açığı ekonomik kırılganlığı artıran diğer bir faktör olarak kabul edilmektedir. (Göçer ve Akın, 2016: 207). Tasarrufların düşük olması ülkenin dış tasarruflara olan ihtiyacını arttırmaktadır. Yabancı sermayenin bollaşması için izlenen politikalar yerli paranın değerlenmesine ve açık pozisyon artışına neden olmaktadır. $\mathrm{Bu}$ gelişmeler yerli firmaların dış piyasalarda rekabet güçlerini zayıflatmakta ve dolaysıyla ekonomide kırılganlığın artmasına neden olabilmektedir.

Düşük rezerv oranına ve zayıf para birimine sahip gelişmekte olan ülkelerde siyasi istikrarsızlık ve tekrar seçilebilmek kaygısı politikacıları kısa vadeli ekonomi politikalarını uygulamaya zorlamaktadır. $\mathrm{Bu}$ nedenle 
uygulanan makroekonomik politikaların yönü sık sık değișebilmektedir. Politika değişimlerindeki sıklık yatırım ve üretim kararlarını olumsuz etkilemekte, siyasi belirsizliği de arttırmaktadır. İktidarın sürekli el değiștirmesi de bu ülkelerde yerli ve yabancı sermaye yatırımlarının azalmasına, spekülatif yatırımın artmasına neden olmaktadır. $\mathrm{Bu}$ durum ise seçim öncesi ve sonrasinda da kırılganlığı artırmaktadır (Bussiere ve Mulder, 1999: 17).

Ekonomik kırılganlık ile ilgili diğer önemli konu ise ölçümüdür. Ancak ekonomik kırılganlığın tespit ve ölçümünde seçilen göstergeler ve kullanılan yöntemler farkllılk göstermektedir. Ekonomik kırılganlığın ölçümünde en doğru sonucu elde edebilmek için seçilen göstergelerin kamu, özel sektör ve hane halkını kapsaması gerekmektedir. Çünkü ekonomiler stres altındayken, bir sektördeki sorunlar kolayca diğer sektörleri etkileyebilmekte ve de yayılabilmektedir. Örneğin, bir ülkenin net borçlanma gereği hususundaki endişeler döviz kurunun artmasına neden olabileceği gibi devlet borçlanma senetlerine sahip bankalara olan güvene de zarar verebilir. Böylece bu gelişmeler ekonomik krizi tetikleyebilir (IMF, 2008:1).

Literatürde makroekonomik kırılganlı̆̆ın ölçülmesinde "regresyon analizi" ve "sinyal" yaklaşımı yaygın olarak kullanılmaktadır. Çok değişkenli regresyon yaklaşımı, büyüme krizinin olasıllğını tahmin etmek için panel probit modeli kullanmaktadır. Bu yaklaşım, farklı değişkenler arasındaki korelasyonların hesaba katılmasına, bireysel değișkenlerin istatistiksel öneminin test edilmesine ve ülke grupları arasında katsayıların sürekliliğinin değerlendirilmesine izin vermektedir.

Sinyal yaklaşımı, kırılganlık göstergelerinin her birini ayrı ayrı hesaba katmakta, en düşük tahmin hatasıyla kritik eşik değeri tespit etmekte ve ardından da göstergelerin ağırlıklarını dikkate alarak endeks değerini belirlemektedir. Özellikle kompozit endeks, eşik değerini aşan göreceli sinyal gücü ile ağırlıklandırılmış göstergelerin sayısını dikkate almaktadır. Bu yaklaşım, ülkeler arasında veri kullanılabilirliğindeki

farklılıkları barındırabilir ve çok değişkenli regresyon yönteminden potansiyel olarak daha fazla sayıda kırılganlık göstergesinin dâhil edilmesine olanak tanımaktadır. Aynı zamanda, probit analizinden elde edilen sonuçlar, tek değişkenli yaklaşımda kullanılan değişkenin koşullu istatistiksel önemi konusunda rehberlik sağlamaktadır (Dabla-Norris ve Gündüz, 2014:361).

Dışa açık ekonomilerin kırılganlı gösterme ihtimali yüksek olarak kabul edilmektedir (Briguglio vd., 2008:1; Atkins vd., 2000:32). Çünkü sürdürülebilir büyüme için yabancı sermaye ihtiyacı ve yabancı sermayenin ülkeye hızlı giriş çıkışı özellikle gelişmekte olan ekonomilerde kırılganlı̆̆ın nedeni olarak görülmektedir. Çin, 1978'den sonra açık kapı politikasıyla yabancı sermayeyi ülkesine çekmeye ve ihracata dayalı büyüme politikası uygulamaya başlamıştır. 2001 yılına gelindiğinde Dünya Ticaret Örgütü (DTÖ) üyeliği ile birlikte Çin dış dünya ile ilişkilerini giderek arttırmaya başlamıştır. Değişimle birlikte 2000-2018 arasında bir taraftan ortalama yüzde ondan daha yüksek oranda büyümüş ve 2018'de kişi başına milli gelirini yaklaşık olarak on bin dolara yaklaştırmış, diğer taraftan da ekonomik küreselleşmenin yol açtığı dışsal şok ve rahatsızlıklara maruz kalmaya başlamıştır. Dolaysıyla, Çin ekonomisinde büyümenin sürdürülebilirliği açısından kırılganlık ile büyüme arasındaki ilişkinin incelenmesi önem taşımaktadır.

Literatürde ekonomik büyüme ile kırılganlık arasındaki ilişkiyi inceleyen çok az sayıda çalışma mevcuttur. Bunlar arasında Çin ekonomisinde makroekonomik kırılganlı ile büyüme arasında nedensellik ve nedenselliğin yönünü belirlemeye yönelik ekonometrik modellerin tahminine dayanan uygulamalı bir çalışmaya rastlanılmamıștır. $\mathrm{Bu}$ yönüyle çalışmanın literatüre katkı sağlayacağı düşünülmektedir.

$\mathrm{Bu}$ çalışmanın amacı, Çin ekonomisinde makroekonomik kırılganlık ile büyüme 
arasındaki nedensellik ilișkisini araștırmaktır. Çalışmada giriş kısmının ardından ikinci kısımda makroekonomik kırılganlık göstergeleri açıklanmaktadır. Üçüncü kısımda literatür araştırılması üzerinde durulmakta, dördüncü kısımda ise çalışmanın ampirik analizinde kullanılacak veri seti tanitılmakta, kullanılan ampirik yönteme ilişkin bilgiler aktarılmakta ve bulgular değerlendirilmektedir. Son kısımda ise ulaşılan sonuçlara ilişkin genel bir değerlendirme yaplarak politika önerilerine yer verilmektedir.

\section{MAKROEKONOMİK KIRILGANLIK GÖSTERGELERI}

Xiaoping dönemi ile başlayan reformlar Çin'in ekonomik göstergelerinde değișmeler yaratmıştır. Göstergelerdeki söz konusu değişmeler ekonomideki kırılganlığı etkilemesi açısından önem arz etmektedir. Çalışmanın bu bölümünde makroekonomik kırılganlığı ölçmek için Çin'e ait aynı zamanda FED'inde tercih ettiği göstergeler ele alınmıştır.

\subsection{Cari Dengenin GSYİH'ye Oranı}

Çin reformların başladığı ilk günden buyana dış ticaret politikasını istikrarlı bir șekilde fazla vermek üzere inşa etmiştir. 1990'lı yılların başından beri doğrudan yatırımla gelen yabancı firmaların ile yerli firmaların ihracat performansı dış ticaret fazlası yaratmıştır. Çin'in ucuz emek gücüne sahip olması ve yüksek teknolojili ürün ihraç eden ülke konumuna gelmesi dıș ticaret fazlası vermesinde önemli rol oynamıştır (Wang, 2006:72). 2008 krizi diğer ülkeler gibi Çin'i de olumsuz etkilemiştir. 2008 yılında 349 milyar dolar olan dıș ticaret fazlası 2009'da220 milyar dolara, 2011'de ise 180 milyar dolara gerilemiştir. Takip eden yılarda, 2015 yılı hariç, dış ticaret fazlası 300 milyar doların altında kalmıştır. Diğer önemli bir nokta ise Çin kriz öncesi otuz yıllık dönemde Çin dış ticaret hacmini iki, üç yıllık periyotlarda ikiye katlarken (Feenstra ve Wei, 2010:30-31) krizden sonra ancak on yılda iki katına çlkarabilmiştir (World Bank, 2019: data.worldbank).
Tablo 1: Cari Dengenin GSYIH'ye Oranı (World Bank,2019: data.worldbank)

\begin{tabular}{|c|c|c|c|}
\hline Yillar & $\begin{array}{c}\text { Cari Denge/ } \\
\text { GSYIH }\end{array}$ & Yillar & $\begin{array}{c}\text { Cari Denge } \\
\text { /GSYIH }\end{array}$ \\
\hline $\mathbf{1 9 8 7}$ & 0,001 & $\mathbf{2 0 0 3}$ & 0,026 \\
\hline $\mathbf{1 9 8 8}$ & $-0,012$ & $\mathbf{2 0 0 4}$ & 0,035 \\
\hline $\mathbf{1 9 8 9}$ & $-0,012$ & $\mathbf{2 0 0 5}$ & 0,058 \\
\hline $\mathbf{1 9 9 0}$ & 0,033 & $\mathbf{2 0 0 6}$ & 0,084 \\
\hline $\mathbf{1 9 9 1}$ & 0,035 & $\mathbf{2 0 0 7}$ & 0,099 \\
\hline $\mathbf{1 9 9 2}$ & 0,015 & $\mathbf{2 0 0 8}$ & 0,092 \\
\hline $\mathbf{1 9 9 3}$ & $-0,026$ & $\mathbf{2 0 0 9}$ & 0,048 \\
\hline $\mathbf{1 9 9 4}$ & 0,012 & $\mathbf{2 0 1 0}$ & 0,039 \\
\hline $\mathbf{1 9 9 5}$ & 0,002 & $\mathbf{2 0 1 1}$ & 0,018 \\
\hline $\mathbf{1 9 9 6}$ & 0,008 & $\mathbf{2 0 1 2}$ & 0,025 \\
\hline $\mathbf{1 9 9 7}$ & 0,038 & $\mathbf{2 0 1 3}$ & 0,015 \\
\hline $\mathbf{1 9 9 8}$ & 0,031 & $\mathbf{2 0 1 4}$ & 0,023 \\
\hline $\mathbf{1 9 9 9}$ & 0,019 & $\mathbf{2 0 1 5}$ & 0,028 \\
\hline $\mathbf{2 0 0 0}$ & 0,017 & $\mathbf{2 0 1 6}$ & 0,018 \\
\hline $\mathbf{2 0 0 1}$ & 0,013 & $\mathbf{2 0 1 7}$ & 0,016 \\
\hline $\mathbf{2 0 0 2}$ & 0,024 & $\mathbf{2 0 1 8}$ & 0,004 \\
\hline
\end{tabular}

Tablo 1'e göre Çin 1994 yılından sonra hep cari fazla vermiștir. 2000'den 2008 yılına kadar cari fazlanın GSYİH'ye oranı sürekli artmış, bu yıldan sonra söz konusu oran sürekli düşmüş ancak cari açığa dönüşmemiştir. Diğer bir ifade ile Çin'in sürekli cari fazlası ekonomik kırılganlığını azaltan temel unsur olmaya devam etmiștir. 2008 krizi öncesinde, Çin'in sahip olduğu yüksek cari fazla bu ülkede dış şoklara ve krize karşı kalkan görevi üstlenmiş ve kırılganlığın azalmasında önemli rol üstlenmiştir. 2014-2015 yıllarını kapsayan küçük çaplı finansal kriz ve GSYİH'deki artış cari fazla/GSYİH'nın en düşük seviyeye inmesine neden olmuştur.

\subsection{Bankaların Özel Sektöre Kullandırdığı Yurt İçi Kredilerin GSYIH'ye Oranı}

Bankaların özel sektöre kullandırdığı yurt içi kredilerin GSYIH'ye oranı ekonomik kırılganlığ ve aynı zamanda finansal derinliği ölçmede de kullanılmaktadır. $\mathrm{Bu}$ orandaki artış özel sektörün bankalara olan borcunun ve finansal derinliğin arttığını göstermektedir. 
Tablo 2: Bankaların Özel Sektöre Kullandırdığı Yurt İçi Kredilerin GSYİH'ye Oranı (World Bank, 2019: data.worldbank)

\begin{tabular}{|c|c|c|c|}
\hline Yllar & Kredi/GSYİH & Ylllar & Kredi/GSYIH \\
\hline $\mathbf{1 9 8 7}$ & 0,762 & $\mathbf{2 0 0 3}$ & 1,255 \\
\hline $\mathbf{1 9 8 8}$ & 0,720 & $\mathbf{2 0 0 4}$ & 1,186 \\
\hline $\mathbf{1 9 8 9}$ & 0,751 & $\mathbf{2 0 0 5}$ & 1,118 \\
\hline $\mathbf{1 9 9 0}$ & 0,840 & $\mathbf{2 0 0 6}$ & 1,091 \\
\hline $\mathbf{1 9 9 1}$ & 0,863 & $\mathbf{2 0 0 7}$ & 1,058 \\
\hline $\mathbf{1 9 9 2}$ & 0,844 & $\mathbf{2 0 0 8}$ & 1,020 \\
\hline $\mathbf{1 9 9 3}$ & 0,950 & $\mathbf{2 0 0 9}$ & 1,244 \\
\hline $\mathbf{1 9 9 4}$ & 0,844 & $\mathbf{2 0 1 0}$ & 1,266 \\
\hline $\mathbf{1 9 9 5}$ & 0,831 & $\mathbf{2 0 1 1}$ & 1,231 \\
\hline $\mathbf{1 9 9 6}$ & 0,885 & $\mathbf{2 0 1 2}$ & 1,289 \\
\hline $\mathbf{1 9 9 7}$ & 0,965 & $\mathbf{2 0 1 3}$ & 1,343 \\
\hline $\mathbf{1 9 9 8}$ & 1,051 & $\mathbf{2 0 1 4}$ & 1,407 \\
\hline $\mathbf{1 9 9 9}$ & 1,103 & $\mathbf{2 0 1 5}$ & 1,532 \\
\hline $\mathbf{2 0 0 0}$ & 1,110 & $\mathbf{2 0 1 6}$ & 1,576 \\
\hline $\mathbf{2 0 0 1}$ & 1,099 & $\mathbf{2 0 1 7}$ & 1,570 \\
\hline $\mathbf{2 0 0 2}$ & 1,173 & $\mathbf{2 0 1 8}$ & 1,611 \\
\hline
\end{tabular}

Yükselen ekonomilerde bankaların özel sektöre kullandırdığı yurt içi kredilerdeki artış küresel faktörlerin yanı sıra ulusal para birimlerinin değer kazanmasından ve uzun vadeli düşük faiz oranlarından kaynaklanmaktadır. Yine bu oranın sağlıklı bir şekilde büyümesi düşük makroekonomik kırılganlığın yanı sıra sağlam ve büyük bir ulusal bankacılık sisteminin bir sonucudur (Jimborean, 2016: 18).

Tablo 2'ye göre Çin ekonomisinde 1987-2018 döneminde bankaların özel sektöre kullandırdığı kredilerin GSYİH'ye oranı artış eğilimindedir ve 1998'den sonra hep yüzde yüzün üzerinde seyretmiștir. 2008 finansal krizi ile gelişmiş ülkelerin durgunluğa girmesi Çin mallarına olan talebi daraltmıştır. Çin'in ihracatında meydana gelen yavaşlama ekonomik büyümesinin de yavaşlamasına neden olmuştur. Yaşanan bu durum Çin hükümetinin iç talep ve yatırımlara daha fazla ağırlık vermesine neden olmuştur. Böylece yapılan düzenlemelerle Çin bankalarının daha fazla kredi vermeleri sağlanmıștır. 2008 ile 2018 arasında ise işaret tersine dönmüş, pozitif değer almıştır. Bu orandaki en fazla yüzdesel artışlar 2009 ile 2015 yıllarında yaşanmıştır. 2009 yılındaki artışın nedeni küresel krizin ekonomik büyümeyi durdurmasını, 2015'deki artışın gerekçesi de borsa krizinin derinleşmesini engellemektir.

Küresel krizden sonra Çin'de bankaların özel sektöre kullandırdığı yurt içi kredilerin GSYİH'ye oranı 2018'de yüzde yüz altmışı geçmiş olmasına rağmen takipteki kredilerinin toplam krediler içindeki payı yüzde ikiye ulaşmamıştır. $\mathrm{Bu}$ oranlar BRICS ülkeleri içerisinde Çin bankalarını en yüksek varlık kalitesine sahip ve en güçlü kredi profiline sahip bankalar konumuna getirmektedir (World Bank, 2019: data.worldbank).

\subsection{Toplam Dış Borcun Yıllık İhracata Oranı}

Toplam dış borcun ihracata oranı, bir ekonominin ihracattan elde edilen gelir ile dış borcunu ödeyebilme yeteneğini gösterir. $\mathrm{Bu}$ oranının yüksek ve yükseliyor olması o ülkenin dış borçlarını geri ödeme yeteneğinin azaldığını ve dolayısıyla kırılganlığının arttığını göstermektedir. Diğer bir ifade ile bu oranın birin altında bir değer alması, borcun teorik olarak bir yıldan daha kısa sürede ve hızlı bir şekilde geri ödenebileceğini göstermektedir. Çin için bu oran değerlendirildiğinde Şekil 1'e göre 2000-2008 arasında ihracatın büyüme hızı diş borç büyüme hızından fazla olduğundan bu süre içinde bu oran sürekli azalmıştır. 2008'den sonra ise dış borç ihracattan daha yüksek büyüyünce söz konusu oran sürekli artmıştır. Örneğin, 2008 yılında Çin toplam dış borçlarının dört katı, 2018 yılına gelindiğinde ise bir buçuk katı kadar ihracat yapmıştır (World Bank, 2019: data.worldbank).

Günümüzde de uluslararası bir standart olarak, dış borcun sürdürülebilirliği için dış borcun ihracata oranının eşik değeri yüzde yüz elli olarak kabul edilmektedir (IMF, 2003: 173; Kidochukwu, 2015:83). Çin'in diş borcunun ihracatına oranı bu standarttın oldukça altındadır. Kısaca, Çin'in cari işlem dengesi kötüleşse ve Yuan gelecekte değer kaybetse bile, Çin'in dış borç yükleri yakın ve orta vadede sürdürülebilir olarak gözükmektedir. 
Dış Borç/ ihracat

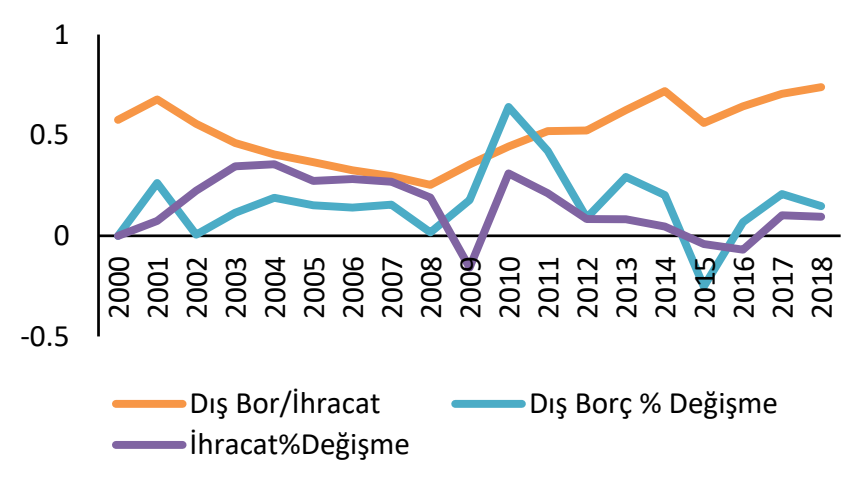

Şekil 1:Toplam Dış Borcun Yıllık İhracata Oranı (World Bank,2019)

\subsection{Döviz Rezervlerinin GSYİH'ye Oranı}

Ekonomilerin yeterli döviz rezervi bulundurma sebebi, iç ve dış şoklara karşı korunmak, ekonomik güveni arttırmak ve dış borçlarının ödemelerini rahatça yapabilmektir. Diğer bir ifade ile rezerv seviyesinin yüksek olması o ülkenin likidite krizlerini önleme kabiliyetini artırmakta, ekonomide kırılganlığ azaltmaktadır (IMF, 2008: 1).

\section{Döviz Rezervi/GSYIH}

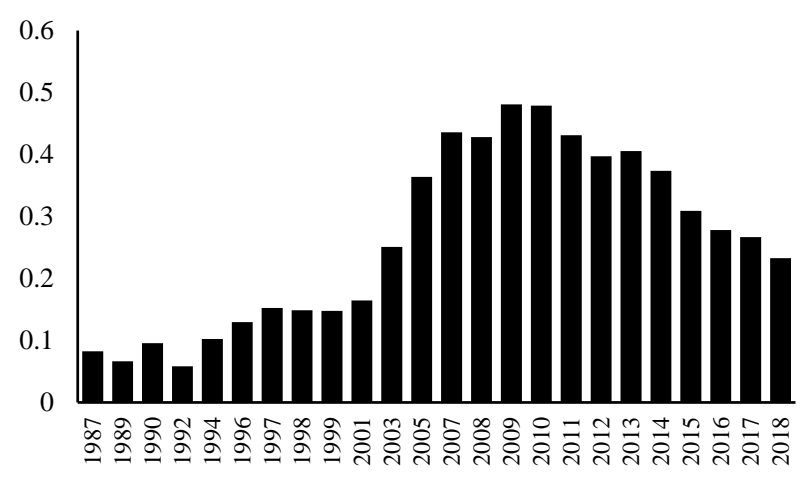

Şekil 2:Toplam Dış Borcun Yıllık İhracata Oranı (Worldbank,2019: data.worldbank)

Çin'in hızlı büyümesi ulusal tasarruf oranını ve döviz rezerv birikimini artırmıştır. Çin'in altın dahil 2018 yllındaki toplam rezervi 3168,2 milyar Amerikan doları olmuştur. Yabancı paralar cinsinden rezervlerinin yaklaşık yüzde altmış yedisini Amerikan doları, yüzde yirmi beşini avro olarak tutmaktadır. Asya krizinden önemli ders çlkaran Çin, yüksek oranda likit döviz rezervi tutmaktadır. Çünkü likit döviz rezervleri hükümete rezervleri doğrudan kontrol etme ve ani bir ihtiyaç durumunda kendi takdirine bağlı olarak kullanma imkanı vermektedir. Dahası, döviz talebine hızlı ve güçlü bir şekilde yanıt verebilme yeteneği, Çin makamlarının finansal piyasalardaki kredibilitesini artırmaktadır.

Şekil 2'ye göre küresel krize kadar Çin'in toplam rezervlerinin GSYIH'sine oranı artmıştır. Bu oran 2009-2010 yılında zirve yaptıktan sonra azalmaya başlamıştır. GSYIH'deki büyümenin düşmesi ve merkez bankasının 2014'ten buyana Yuan'ın değerini korumak amacıyla dolar satması döviz rezervlerinin hızlı ve önemli ölçüde erimesine neden olmuştur. 2014'te 3900 milyar dolara çlkan döviz rezervi 2018'te 3168,2 milyar dolara düşmüştür. Bu düşüşün temel nedenleri olarak Çinli firmaların diş borç geri ödemesi ve yerleşiklerin yabancı varlık talebindeki artış gösterilmektedir. Rezervlerin daha hızlı azalmasını istemeyen politika yapıcıları 2015'te kurumlar ve özel işçi dövizleri üzerindeki sermaye kontrollerini artırmıştır (Neely, 2017:10-16). Kontrollerin artması döviz rezervlerinin GSYİH'ye oranındaki azalmayı durduramamıştır. Tüm bunlara rağmen Çin halen dünyanın en çok döviz rezervine sahip ülkesidir ve durum kırılganlığını azaltmaktadır (World Bank, 2019: data.worldbank).

\subsection{Kamu Borcunun GSYİH'ye Oranı}

Çin'in kamu borç yapısı incelendiğinde birkaç husus dikkat çekmektedir. Bunlardan birincisi, Çin'in toplam kamu borcu, merkezi yönetim ve yerel yönetim borcundan oluşmaktadır. IMF bu borç kaynaklarını genel yönetim borcu olarak birleştirmektedir. İkincisi, gelişmekte olan diğer ülkelerin aksine diş borçlanmaya çok sıcak bakmayan bir ülke olması nedeniyle Çin'in kamu borcunun önemli bir kısmı iç borçlardan oluşmaktadır (NBSC, 2019). Üçüncüsü, 2001'den itibaren kısa vadeli borçların toplam borç içerisinde payı artmış ve kamu finansmanı açısından bir tehdit oluşturmaya başlamıştır (NBSC, 2019). 
Tablo 3: Ödenmemiș Merkezi Hükümet Borcu /GSYİH (NBSC,2019)

\begin{tabular}{cccc}
\hline Yillar & $\begin{array}{c}\text { Kamu Borcu } \\
\text { /GSYiH }\end{array}$ & Yllar & $\begin{array}{c}\text { Kamu Borcu } \\
\text { /GSYIH }\end{array}$ \\
\hline $\mathbf{1 9 8 7}$ & 0,018 & $\mathbf{2 0 0 3}$ & 0,045 \\
$\mathbf{1 9 8 8}$ & 0,018 & $\mathbf{2 0 0 4}$ & 0,043 \\
$\mathbf{1 9 8 9}$ & 0,024 & $\mathbf{2 0 0 5}$ & 0,174 \\
$\mathbf{1 9 9 0}$ & 0,020 & $\mathbf{2 0 0 6}$ & 0,160 \\
$\mathbf{1 9 9 1}$ & 0,021 & $\mathbf{2 0 0 7}$ & 0,193 \\
$\mathbf{1 9 9 2}$ & 0,025 & $\mathbf{2 0 0 8}$ & 0,167 \\
$\mathbf{1 9 9 3}$ & 0,021 & $\mathbf{2 0 0 9}$ & 0,173 \\
$\mathbf{1 9 9 4}$ & 0,024 & $\mathbf{2 0 1 0}$ & 0,164 \\
$\mathbf{1 9 9 5}$ & 0,025 & $\mathbf{2 0 1 1}$ & 0,147 \\
$\mathbf{1 9 9 6}$ & 0,027 & $\mathbf{2 0 1 2}$ & 0,144 \\
$\mathbf{1 9 9 7}$ & 0,031 & $\mathbf{2 0 1 3}$ & 0,146 \\
$\mathbf{1 9 9 8}$ & 0,039 & $\mathbf{2 0 1 4}$ & 0,149 \\
$\mathbf{1 9 9 9}$ & 0,041 & $\mathbf{2 0 1 5}$ & 0,155 \\
$\mathbf{2 0 0 0}$ & 0,042 & $\mathbf{2 0 1 6}$ & 0,161 \\
$\mathbf{2 0 0 1}$ & 0,042 & $\mathbf{2 0 1 7}$ & 0,163 \\
$\mathbf{2 0 0 2}$ & 0,047 & $\mathbf{2 0 1 8}$ & 0,163 \\
\hline
\end{tabular}

Çalışmada toplam kamu borcunu temsilen merkezi hükümet borcunun GSYİH'ye oranı dikkate alınmıştır. 2004 yılına kadar büyük bir değişiklik göstermeyen merkezi hükümet borcunun GSYIH'ye oranı 2004 yılında yaşanan yönetim değişikliği nedeniyle Tablo 3'e göre 0,174 seviyesine yükselmiştir. Diğer bir ifade ile 2004-2005 arasında merkezi hükümet borcunun GSYIH'ye oranı 4 kattan fazla artmıştır. Küresel finansal krizle bir kez daha sıçrama yapan bu oran bir daha 1990'lı yıllar düzeyine geri gelmemiştir. Daha sonra 2014 yılında finansal sektördeki dalgalanma bu oranın yükselmesine sebep olmuştur (Sun, 2019: 11). Bütün bunlara rağmen söz konusu bu oranın yüzde ellinin üzerine çıkmamış olması, enflasyon oranının yüzde iki civarında olması borcun sürdürülebilirliğini göstermektedir. Ancak Çin'in büyümesinin yavaşlaması kamu borcunun GSYİH'ye oranı yıldan yıla artırmakta ve artışın devam etmesi makroekonomik kırılganlığı artırmaktadır.

\subsection{Enflasyon Oranı}

Enflasyon oranının kirılganlık hesaplanmasında kullanılmasının nedeni para ve diğer makro politikalardan kolayca etkilenmesidir. Bir ekonomide yüksek enflasyon varsa o ekonomi negatif şoklardan daha çok etkilenebilmektedir.

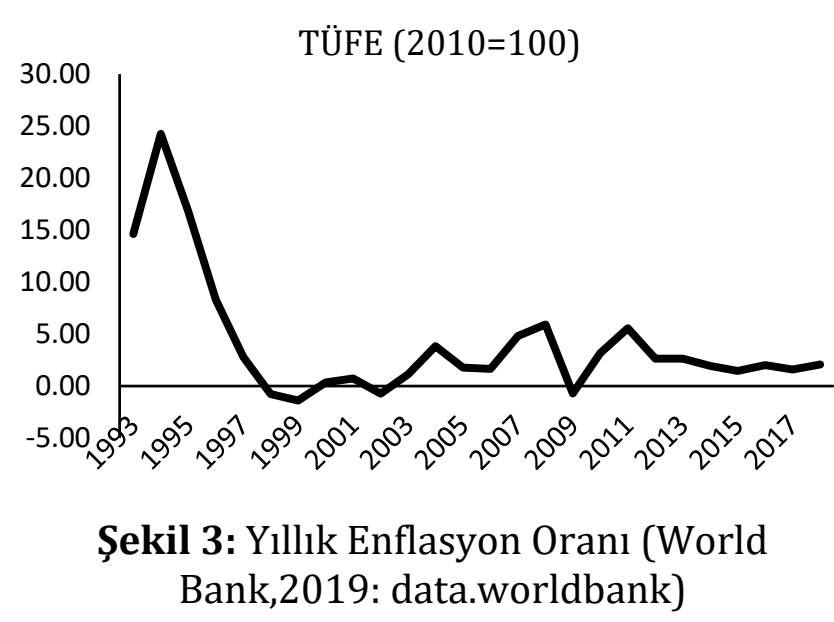

Şekil 3'e göre Çin son yirmi yılda çift haneli enflasyon yaşamamış, en yüksek enflasyonu $\% 5,9$ olarak 2008 yılında yaşamıştır. 2008 enflasyonunda enerji, gıda ve konut fiyatları ve ABD'deki finansal kriz önemli rol oynamıştır (Yuanchun, 2015:4-5). 2009'da fiyatlar aniden düşmüş olmasına rağmen devam etmemiş ve 2011'de eski seviyesine geri dönmüştür.

2012'den buyana Çin'de yıllık enflasyon \%2 civarında seyretmektedir. İmalat sanayindeki aşırı kapasite kullanımı üretici fiyatları üzerinde aşağı yönlü bir baskı yaratmaktadır. $\mathrm{Bu}$ baskı dayanıklı tüketim malları gibi bileşenler yoluyla da tüketici fiyatlarını düşürmektedir. Tüketici fiyatlarının azalmasına katkıda bulunan diğer bir faktör ise 2015'in ilk yarısına kadar Yunan'ın değer kazanması ve ithal mallarının fiyatındaki azalıştır. 2018 Ocak-Kasım döneminde enerji ve gıda fiyatlarındaki artış enflasyonu tekrardan \%2'nin üzerine çıkarmıștır. Bu rakamlar bazı ülkelere göre aşırı yüksek olmasa da sosyalist sistemi yaşamış bir ekonomi için fiyatların bu kadar hareketli olması alışılmış bir durum değildir.

\section{LİTERATÜR İNCELEMESİ}

Makroekonomik kırılganlık büyüme ilişkisi son zamanlarda dikkat çeken konulardan biri olmuştur. Bununla birlikte konu ile ilgili geniş bir literatürün varlığından bahsetmek neredeyse mümkün değildir. Konuyu inceleyen 


\section{BAYLAN}

çalıșmaların azlığına rağmen çalıșmalarda değişkenler arasındaki ilişki ve ilişkinin yönü hakkında farklı sonuçlara rastlamak mümkündür. Çalışmaların bir kısmında kırılganlığın büyüme üzerinde olumsuz bir etkiye sahip olduğu vurgulanmaktadır. $\mathrm{Bu}$ konuda yapılmış en güncel çalıșmalardan biri Lepers ve Serrano'a aittir. Lepers ve Serrano (2020) otuz iki göstergeyi kullanarak yükselen ekonomiler için kırılganlı indeksi oluşturduktan sonra büyüme ile kırılganlık arasında ilişkiyi incelemiștir. Finansal kırılganlığın merkeze alındığı çalışmada Arjantin, Brezilya, Malezya, Meksika, Rusya, Suudi Arabistan, Güney Afrika ve Türkiye için iki değișken arasında pozitif, Çin, Hindistan ve Endonezya için ise negatif korelasyonun var olduğunu tespit edilmiştir. Ayrıca yazarlara göre değişkenler arasındaki negatif korelasyon pozitif korelasyondan daha büyüktür. Briguglio vd. (2008) çalışmalarında ekonomik kırılganlık ile kişi başına düşen GSYIH arasındaki ilişkiyi standardize edilmiş verileri kullanarak EKK yöntemi ile incelemişlerdir. Elde ettikleri sonuçlara göre ekonomik kırılganlık kişi başına düşen GSYİH'yi negatif, ekonomik dayanıklılık ise GSYIH'yi pozitif etkilemektedir. Ayrıca zengin ülkelerde ekonomik dayanıklılık ile kişi başına düşen GSYIH arasındaki ilişki diğer ülkelere nazaran daha kuvvetlidir. Gounder ve Saha (2007) ise söz konusu değișkenler arasındaki ilişkiyi altı güney pasifik adası ülkesi için 1971-2003 dönemini kapsayan veriler ve genelleştirilmiş EKK yöntemiyle test etmiştir. Elde edilen sonuçlara göre kırılganlık ada ülkelerinin büyüme oranlarını yavaşlatmakta ve aynı zamanda farklı kalkınma düzeylerindeki ekonomiler arasındaki yakınsama hızını da azaltmaktadır. Afrika ülkeleri için finansal kırılganlığın büyüme üzerindeki etkisini inceleyen Fowowe ve Folarin (2019) kırılganlığın büyümeyi negatif etkilediğini belirlemiştir.

Diğer bir kısım çalışma ise yukarıdaki görüşe katılmayıp kırılganlık ile büyüme arasında pozitif ilişkinin varlı̆̆ını ileri sürmektedir. Bunlardan biri Armstrong ve Read'e aittir. Armstrong ve Read (2002), Briguglio'in (1995) hesapladığı kırılganlık indeksini kullanarak kiși başına GSYİH'deki büyüme ile kırılganlık arasında negatif değil, pozitif bir korelasyon olduğunu göstermiş ve bu nedenle kırılgan ülkelerin dezavantajlı olduğu iddiasının geçersiz olduğunu ileri sürmüştür. DablaNorris ve Gündüz (2014) ise düşük gelirli ülkeler için probit regresyon ve sinyal yaklaşımlarını kullanarak yeni bir indeks geliştirmiştir. Elde ettikleri indeks değerlerine göre düşük gelirli ülkelerin çoğu küresel krizden bu yana hızlı bir șekilde toparlanmıș ve 2010'dan bu yana da güçlü bir şekilde büyümüștür. Bununla birlikte bu ülkelerin ekonomik kırılganlıkları da kriz öncesi döneme kıyasla yükselmeye devam etmiștir.

Cordina (2004) göre kırlganlık ile büyüme arasındaki ilişkiyi ülkelerin gelişmişlik düzeyleri belirlemektedir. O'na göre kırılgan az gelişmiş ekonomiler kişi başına sermaye stoku ile üretim düzeylerini yükseltme, tüketim ile kamu harcamalarını ise düşürme eğilimindedirler. Dışsal şokların etkilerinin üstesinden gelmek için izlenen bu politika bir yandan sermayenin marjinal verimliliğini düşürmekte diğer taraftan ise tüketimi azaltarak refahın azalmasına neden olmaktadır. Gelişmiş ekonomilerin sermaye birikimi sorunu olmadığından ekonomik kırılganlık az gelişmiş ekonomilerin büyümesini yavaşlatırken, gelişmiş olanlarınkini artırmaktadır. Dolayısıyla, kırılganlık farklı gelişmişlik düzeylerine sahip ekonomiler arasında yakınsama hızını azaltmaktadır.

Melville ve Brathwaite (2006) ekonomik kırılganlık ile kişi başına düșen GSYİH arasında zayıf ve önemsiz bir korelasyon olduğunu ileri sürerken, Jimborean (2016) ise kırılganlığın büyümeyi değil de büyümenin kırılganlığı azalttığını ileri sürmüştür.

Çin için yapılmış çalışmalardan da elde edilen sonuçlar farklılık göstermektedir. Ren vd (2018)'e göre Çin'in bölgelerinin büyümesi ile ekonomik kırılganlığı arasındaki ilişki ters yönlüdür. Doğu, Orta ve Kuzeydoğu Çin'de il ekonomilerinin kırılganlığı komşu illerin ekonomik büyümesi üzerinde olumsuz, Batı 
Çin'de ise hafif bir pozitif yayılma etkisine sahiptir. Ansar vd (2016)'da Çin'in yatırım harcamalarını borçlanarak ve olağanüstü parasal genişleme ile finanse etmesinin ekonomik ve finansal kırılganlığa yol açtığı, ancak ekonomik büyümeye yol açmadığı sonucuna varmışlardır. Sun (2018) çalışmasında kapsamlı bir borç seti ve eşik değer tahmini kullanarak Çin'in borç yapısının gelişimini incelemiştir. Elde edilen sonuçlar merkezi hükümet ve dış borçlarından oluşan kamu borcunun sürdürülebilir olduğunu, buna karşın yüksek miktarda borçlu yerel yönetimlerin, finansal olmayan şirketlerin ve gölge bankaların finansal kırılganlığı artırdığını göstermiştir. Bayraktar ve Elüstü (2016) ise 2000'lerin başından itibaren yükselen ekonomilerin uygun dış koşulların da etkisiyle hızlı büyüdüklerini ve hızlı büyümenin ise var olan kırılganlıklarını daha da arttırdığını vurgulamıştır. Yazarlar seçili ülkeler arasında Çin'in yüksek derecede bir kırılganlığının olmadığını tespit etmiştir. Son olarak, Türkiye ve Şangay Beşlisini makroekonomik kırılganlık açısından değerlendirdiği çalışmasında Karakurt vd. (2015) Türkiye'yi en fazla, Çin'i ise en az kırılgan ülke olarak nitelendirmektedir. Yazarlara göre Çin'in uluslararası rekabet gücü avantajı, dünyada önemli düzeyde ve çeşitlilikte pazara sahip olması, cari fazla vermesi ve yüksek döviz rezervi ekonomik kırılganlığını azaltmaktadır.

\section{YÖNTEM VE VERI SETI}

Çalışmanın bu bölümünde Çin ekonomisinde makroekonomik kırılganlık ile büyüme arasındaki ilişki ekonometrik yöntemler kullanılarak analiz edilmiştir. $\mathrm{Bu}$ ilişkiyi belirlemek amacıyla, 1987-2018 dönemine ait yıllık verilerden oluşan zaman serileri kullanılmıştır. Zaman serileri oluşturulan değişkenlerden, makroekonomik kırılganlık göstergesi olarak Makroekonomik Kırılganlık Endeksi (MKE), büyüme göstergesi olarak da Amerikan doları cinsinden GSYIH'deki artış oranı (GSYIHH) seçilmiştir.

MKE oluşturmak için Brugliglo $(1995,1997)$ ve Guillaumont (2011)'yi temel alan Aikman vd.
(2015) ve sonra Lepers ve Serrano (2020) tarafından geliștirilen metodoloji takip edilmiştir. MKE'nin hesaplanmasında öncelikle her bir göstergenin değeri ile ortalamasının farkı standart sapmasına bölünerek standartlaştırılmıştır.

$\tilde{X}_{i, t}=\frac{x_{i, t-} \bar{x}_{i, t}}{\sigma\left(x_{i, t}\right)}$

Burada $x_{i}$; t yılındaki değişken değerini, t; yılı, $\bar{x}_{i} ;$ değişkenin aritmetik ortalamasını, $\sigma_{i}$; standart sapmayı ve $\tilde{X}_{i, t}$ ise standardize edilmiş değeri göstermektedir. $\mathrm{Bu}$ yöntemde tüm $\tilde{X}_{i, t}$ 'lerin ülkenin makroekonomik kırılganlık endeksini belirlemede eşit bir ağırlığa sahip olduğunu varsayıldığından MKE'yi oluşturmak üzere $\tilde{X}_{i, t}{ }^{\prime}$ lerin basit bir ortalaması alınmıştır.

$M K E_{i, t}=\frac{1}{i} \sum \bar{x}_{i, t}$

Hesaplanan endeks değerinin büyümesi kırılganlığın arttığı anlamına gelmektedir.

MKE'sinin oluşturulurken 1987 yılının başlangıç seçilmesinin temel nedeni verilere ulaşabilme imkânından kaynaklanmıştır. Çalışmada kullanılan veriler, Cari Dengenin GSYİH'ye Oranı (CA), Enflasyon Oranı (ENF), Toplam Dış Borcun Yıllık İhracata Oranı (DB), Bankaların Özel Sektöre Kullandırdığı Yurt İçi Kredilerin GSYIH'ye Oranı (YK), Döviz Rezervlerinin GSYIH'ye Oranı (DR) ve Kamu Borcunun GSYİH'ye Oranı (KB)'dan oluşmaktadır. Veriler Dünya Bankası ve Çin Ulusal İstatistik Bürosu'ndan elde edilmiștir. $\mathrm{Bu}$ kapsamda, makroekonomik kırılganlık ve büyüme ilişkisini belirlemek için kullanılan regresyon denklemi,

GSYIH $=\beta_{o}+=\beta_{1} M K E+u_{t}$

şeklinde tanımlanmıştır.

\subsection{Makroekonomik Kırılganlık Endeksi (MKE)}

Elde edilen MKE değerleri Tablo 4'de gösterilmiştir. 1987-2018 dönemi MKE değerleri için eşik değer; 0,36 bulunmuştur. Eşik değeri aşan dönemler sinyal olarak kabul edilmiştir. 


\section{BAYLAN}

Tablo 4: Makroekonomik Kırılganlık Endeksi (MKE)

\begin{tabular}{cccccccc}
\hline & CA & ENF & DB & YK & DR & KB & MKE \\
\hline $\mathbf{1 9 8 7}$ & $-0,89$ & 0,33 & 1,27 & $-1,38$ & $-1,12$ & $-1,04$ & $-0,47$ \\
$\mathbf{1 9 8 8}$ & $-1,37$ & 2,13 & 0,93 & $-1,55$ & $-1,17$ & $-1,05$ & $-0,35$ \\
$\mathbf{1 9 8 9}$ & $-1,38$ & 2,04 & 1,47 & $-1,43$ & $-1,24$ & $-0,96$ & $-0,25$ \\
$\mathbf{1 9 9 0}$ & 0,27 & $-0,32$ & 1,60 & $-1,07$ & $-1,03$ & $-1,02$ & $-0,26$ \\
$\mathbf{1 9 9 1}$ & 0,32 & $-0,24$ & 1,45 & $-0,98$ & $-0,82$ & $-1,00$ & $-0,21$ \\
$\mathbf{1 9 9 2}$ & $-0,39$ & 0,19 & 1,45 & $-1,06$ & $-1,29$ & $-0,94$ & $-0,34$ \\
$\mathbf{1 9 9 3}$ & $-1,88$ & 1,48 & 1,73 & $-0,64$ & $-1,27$ & $-1,00$ & $-0,26$ \\
$\mathbf{1 9 9 4}$ & $-0,49$ & 2,98 & 0,99 & $-1,06$ & $-0,98$ & $-0,95$ & 0,08 \\
$\mathbf{1 9 9 5}$ & $-0,85$ & 1,82 & 0,75 & $-1,11$ & $-0,93$ & $-0,94$ & $-0,21$ \\
$\mathbf{1 9 9 6}$ & $-0,63$ & 0,50 & 0,51 & $-0,90$ & $-0,79$ & $-0,90$ & $-0,37$ \\
$\mathbf{1 9 9 7}$ & 0,46 & $-0,36$ & 0,33 & $-0,58$ & $-0,63$ & $-0,85$ & $-0,27$ \\
$\mathbf{1 9 9 8}$ & 0,17 & $-0,92$ & 0,25 & $-0,24$ & $-0,65$ & $-0,73$ & $-0,35$ \\
$\mathbf{1 9 9 9}$ & $-0,24$ & $-1,01$ & 0,20 & $-0,04$ & $-0,66$ & $-0,70$ & $-0,41$ \\
$\mathbf{2 0 0 0}$ & $-0,32$ & $-0,74$ & $-0,45$ & $-0,01$ & $-0,70$ & $-0,69$ & $-0,48$ \\
$\mathbf{2 0 0 1}$ & $-0,46$ & $-0,68$ & $-0,07$ & $-0,05$ & $-0,54$ & $-0,69$ & $-0,42$ \\
$\mathbf{2 0 0 2}$ & $-0,06$ & $-0,91$ & $-0,52$ & 0,24 & $-0,27$ & $-0,61$ & $-0,36$ \\
$\mathbf{2 0 0 3}$ & 0,00 & $-0,62$ & $-0,88$ & 0,57 & 0,07 & $-0,64$ & $-0,25$ \\
$\mathbf{2 0 0 4}$ & 0,34 & $-0,20$ & $-1,09$ & 0,29 & 0,55 & $-0,68$ & $-0,13$ \\
$\mathbf{2 0 0 5}$ & 1,16 & $-0,52$ & $-1,23$ & 0,02 & 0,87 & 1,29 & 0,27 \\
$\mathbf{2 0 0 6}$ & 2,11 & $-0,54$ & $-1,38$ & $-0,08$ & 1,08 & 1,08 & $\mathbf{0 , 3 8}$ \\
$\mathbf{2 0 0 7}$ & 2,66 & $-0,05$ & $-1,49$ & $-0,22$ & 1,38 & 1,57 & $\mathbf{0 , 6 4}$ \\
$\mathbf{2 0 0 8}$ & 2,37 & 0,13 & $-1,65$ & $-0,36$ & 1,33 & 1,18 & $\mathbf{0 , 5 0}$ \\
$\mathbf{2 0 0 9}$ & 0,79 & $-0,91$ & $-1,27$ & 0,52 & 1,70 & 1,27 & 0,35 \\
$\mathbf{2 0 1 0}$ & 0,48 & $-0,30$ & $-0,94$ & 0,61 & 1,69 & 1,13 & $\mathbf{0 , 4 4}$ \\
$\mathbf{2 0 1 1}$ & $-0,28$ & 0,07 & $-0,65$ & 0,47 & 1,35 & 0,89 & 0,31 \\
$\mathbf{2 0 1 2}$ & $-0,02$ & $-0,39$ & $-0,64$ & 0,70 & 1,11 & 0,84 & 0,26 \\
$\mathbf{2 0 1 3}$ & $-0,37$ & $-0,39$ & $-0,26$ & 0,91 & 1,17 & 0,87 & 0,32 \\
$\mathbf{2 0 1 4}$ & $-0,12$ & $-0,50$ & 0,09 & 1,17 & 0,94 & 0,91 & $\mathbf{0 , 4 2}$ \\
$\mathbf{2 0 1 5}$ & 0,06 & $-0,57$ & $-0,50$ & 1,66 & 0,48 & 1,00 & $\mathbf{0 , 3 6}$ \\
$\mathbf{2 0 1 6}$ & $-0,28$ & $-0,48$ & $-0,20$ & 1,83 & 0,26 & 1,10 & $\mathbf{0 , 3 7}$ \\
$\mathbf{2 0 1 7}$ & $-0,35$ & $-0,55$ & 0,03 & 1,81 & 0,18 & 1,13 & $\mathbf{0 , 3 8}$ \\
$\mathbf{2 0 1 8}$ & $-0,80$ & $-0,47$ & 0,16 & 1,97 & $-0,06$ & 1,13 & 0,32 \\
\hline & & & & & & & \\
$\mathbf{1 0 1 0}$ & 4 & -36
\end{tabular}

Tablo 4'e göre 2005'ten sonra birkaç yll hariç bu değer aşılmış ve en yüksek kırılganlık küresel krizden hemen önce ve sonra yaşanmıștır. Bu sonuç, endeksin doğru sonuç verdiğinin göstergesidir. Bazı çalışmalara göre bu aşmaların kriz tehlikesi olarak kabul edilebilmesi için eșik değerin 1,5 katı olması gerekir (Supriyadi, 2014: 15).
Tablo 4'e göre 2017'den sonra herhangi bir kriz tehlikesi gözükmemektedir. Ancak 2011'den buyana MKE'nin yükselme trendinde olduğu görülmektedir. MKE'nin yükselişinde en önemli rolü toplam dış borcun yıllık ihracata oranı ile bankaların özel sektöre kullandırdığı yurt içi kredilerin GSYIH'ye oranının oynadığı söylenebilir.

\subsection{Birim Kök Testi ve Sonuçları}

VAR analizi için zaman serilerinin durağan olması yani serilerin ortalaması ile varyansının sabit olması gerekmektedir (Gujarati, 1999: 713). Durağan olmayan serilerle tahmin edilen modellerde sahte regresyon sorunu yaşandı ̆̆ından analize başlamadan önce birim kök testi yapılır. Bu amaçla, çalışmada kullanılan serilerin durağanlık araştırması en yaygın olarak kullanılan, ADF (Augmented Dickey-Fuller) testi ile yapılmıştır.

Tablo 5: Birim Kök Testi Sonuçları

\begin{tabular}{|c|c|c|c|c|}
\hline \multicolumn{5}{|c|}{ ADF-t istatistiği (Düzey) } \\
\hline Değişkenler & Sabit & $\begin{array}{l}\text { Sabit } \\
\text { ve } \\
\text { Trend }\end{array}$ & $\begin{array}{l}\text { Sabitsiz } \\
\text { ve } \\
\text { Trendsiz }\end{array}$ & $\begin{array}{l}\text { Olasılık } \\
\text { Değeri }\end{array}$ \\
\hline GSYİH & $-2,90$ & $-2,85$ & $-0,89$ & 0,31 \\
\hline MKE & $-1,19$ & $-1,98$ & 0,16 & 0,72 \\
\hline \multicolumn{5}{|c|}{ ADF-t istatistiği (Birinci Fark) } \\
\hline Değişkenler & Sabit & $\begin{array}{l}\text { Sabit } \\
\text { ve } \\
\text { Trend }\end{array}$ & $\begin{array}{l}\text { Sabitsiz } \\
\text { ve } \\
\text { Trendsiz }\end{array}$ & $\begin{array}{l}\text { Olasılık } \\
\text { Değeri }\end{array}$ \\
\hline GSYİH & $-5,68$ & $-5,58$ & $-5,78$ & 0,00 \\
\hline MKE & $-5,02$ & $-4,92$ & $-5,03$ & 0,00 \\
\hline
\end{tabular}

Tablo 5'te gösterilen ADF birim kök testi sonuçlarına göre, serilerin seviyede olasılık değerleri \%5 kritik değerinden büyüktür. Dolaysiyla serilerin seviyede birim kök içerdikleri yani durağan olmadıkları sonucuna varılmıştır. Bu nedenle her iki serininde farkı alınarak yeniden durağanlık testine tabi tutulmuştur. Yine Tablo 5'de sunulan sonuçlara göre, değișkenlerin birinci farklarında birim kök taşıdıkları sıfır hipotezi tüm anlamlılık 
Tablo 6: VAR Analizi Uygun Gecikme Uzunluğu

\begin{tabular}{ccccccc}
\hline Lag & LogL & LR & FPE & AIC & SC & HQ \\
\hline 0 & 45.56457 & NA & 0.000136 & -3.227005 & -3.131018 & -3.198463 \\
$\mathbf{1}$ & 52.36919 & $\mathbf{1 2 . 0 9 7 1 0}^{*}$ & $\mathbf{0 . 0 0 0 1 1 1 *}$ & $\mathbf{- 3 . 4 3 4 7 5 5 ^ { * }}$ & $\mathbf{- 3 . 1 4 6 7 9 1 *}$ & $\mathbf{- 3 . 3 4 9 1 2 8 *}$ \\
2 & 55.11566 & 4.475729 & 0.000122 & -3.341901 & -2.861961 & -3.199190 \\
3 & 56.92122 & 2.674897 & 0.000146 & -3.179350 & -2.507434 & -2.979554 \\
\hline
\end{tabular}

Tablo 7: Diagnostik Testler

\begin{tabular}{lll} 
Hipotez & Olasılık Değeri & Sonuç \\
\hline Modelde otokolerasyon sorunu yoktur. & 0.5894 (LM) & Kabul \\
$\begin{array}{l}\text { Modelde değişen varyans sorunu yoktur. } \\
\text { Modelde kullanılan seriler normal } \\
\text { dağllımlıdır. }\end{array}$ & 0.06676 (Heteroskedasticity) & Kabul \\
\hline
\end{tabular}

düzeylerinde reddedilmiștir. Böylece değişkenlerin birinci farklarında durağan I(1) oldukları kabul edilmiştir.

\subsection{Eş Bütünleşme Testi ve Sonuçları}

Serilerin birinci farkında durağan çıkmaları, GSYİH ve MKE serileri arasinda koentegrasyonun veya uzun dönemli ilişkinin var olup olmadığını araştırmak için gerekli ön koşulu sağlamıştır. Bir sonraki aşama uygun gecikme uzunluğu belirlenmesidir. Tablo 6'da LR (Likelihood), FPE (Final PredictionError), AIC (Akaike Information Criterion), SC (Shwarz Information Criterion), HQ (Hannan-Quinn Information Criterion) kriterlerinden yararlanarak en uygun gecikme uzunluğu tespit edilmiştir. Buna göre, uygun gecikme uzunluğunun tüm bilgi kriterlerine göre 1 olduğu belirlenmiştir.

$\mathrm{Bu}$ aşamadan sonra kurulan modelin otokolerasyon ve değișen varyans sorunu içerip içermediği ile modelde kullanılan serilerin normal dağılımlı olup olmadığı diagnostik testler ile incelenmiștir. Elde edilen diagnostik test sonuçlarına göre, modelde değișen varyans ve otokolerasyon sorunu yoktur, model normal dağılmaktadır. Takip eden aşamada, seriler arasında uzun dönem ilişkisi bulunup bulunmadığı Johansen eş bütünleșme testi ile araștırılmıștır.

Tablo 8'deki Johansen eș bütünleșme testi sonuçlarına göre, büyüme ve makroekonomik kırılganlık arasında uzun dönemde eş bütünleşme ilişkisi vardır. İz istatistiği ve

Tablo 8:Johansen Eş Bütünleşme Testi Sonuçları

\begin{tabular}{llll}
\hline Eș Bütünleșme Sayısı & İz Testi & \%5 Kritik Değer & 0lasılık Değeri \\
\hline $\mathbf{r = 0}$ & 25.17163 & 20.26184 & 0.0097 \\
$\mathbf{r} \leq \mathbf{1}$ & 7.628214 & 9.164546 & 0.0970 \\
\hline Eș Bütünleşme Sayısı & Maksimum Öz Değer Testi & \%5 Kritik Değer & 0lasılık Değeri \\
\hline $\mathbf{r = 0}$ & 17.54342 & 15.89210 & 0.0273 \\
$\mathbf{r} \leq \mathbf{1}$ & 6.233422 & 9.164546 & 0.1734 \\
\hline
\end{tabular}

Tablo 9:Granger Nedensellik/ Blok Dıșsallık WaldTesti Sonuçları

\begin{tabular}{cccc}
\hline Boş Hipotez & Anlamlılık Düzeyi & $\begin{array}{c}\text { Olasılık } \\
\text { Değeri }\end{array}$ & Sonuç \\
\hline $\begin{array}{c}\text { MKE GSYİH'nin nedeni } \\
\text { değildir. }\end{array}$ & 0.05 & 0.0034 & $\begin{array}{c}\text { MKE GSYİH'nin } \\
\text { nedenidir. } \\
\begin{array}{c}\text { GSYİH MKE'nin nedeni } \\
\text { değildir. }\end{array}\end{array}$ CSYİH MKE'nin $^{\text {nedenidir. }}$ \\
\hline
\end{tabular}




\section{BAYLAN}

maksimum öz değer istatistiği \%5 düzeyinde en fazla 1 adet uzun dönem ilişki bulunduğunu göstermektedir. Elde edilen normalize edilmiş eş bütünleşme katsayıları ve denklemi aşağıda gösterilmektedir.

$$
\text { GSYİH }=-0.002074+0.175664 \mathrm{MKE}
$$

$$
\text { (0.00888) (0.08750) }
$$

Normalize edilmiş eş bütünleşme sonuçlarına göre, makroekonomik kırılganlık büyümeyi pozitif olarak etkilemektedir.

\subsection{Nedensellik Testi ve Sonuçları}

Değişkenler arasında kısa dönem nedenselliğin tespiti ve onun yönünü belirlemek için VAR Granger nedensellik/Blok Dışsallık Wald Testi kullanılmıştır. Blok Dışsallık Wald Testin sıfır hipotezi değişkenlerin gecikmeli değerlerinin denklemden dişlanabilirliği olarak tanımlanmaktadır.

Tablo 9:Granger Nedensellik/ Blok Dışsallık WaldTesti Sonuçları

\begin{tabular}{cccc}
\hline $\begin{array}{c}\text { Boş } \\
\text { Hipotez }\end{array}$ & $\begin{array}{c}\text { Anlamlılık } \\
\text { Düzeyi }\end{array}$ & $\begin{array}{c}\text { Olasılık } \\
\text { Değeri }\end{array}$ & Sonuç \\
\hline MKE & 0.05 & 0.0034 & MKE \\
GSYIH'nin & & & $\begin{array}{c}\text { GSYIH'nin } \\
\text { nedenidir. } \\
\text { nedeni }\end{array}$ \\
değildir. & & & \\
GSYİ & 0.05 & 0.0165 & $\begin{array}{c}\text { GSYİH } \\
\text { MKE'nin }\end{array}$ \\
MKE'nin & & & $\begin{array}{c}\text { nedenidir. } \\
\text { nedeni }\end{array}$ \\
değildir. & & & \\
\hline
\end{tabular}

Tablo 9'daki Granger Nedensellik Testi sonuçlarına göre modelde bulunan değişkenler (GSYİH ve MKE) dışsal değildir. Yine test sonuçlarına göre Çin ekonomisinde büyümeden makroekonomik kırılganlığa, makroekonomik kırılganlıktan büyümeye doğru nedensellik ilișkisi mevcuttur. Kısaca, büyüme ile makroekonomik kırılganlık arasında çift yönlü nedensellik ilişkisi vardır.

\section{SONUÇ}

Çin, 1978 yılına kadar dışa kapalı ekonomi modeli seçmiş olmasından dolayı yabancı yatırımcıların ülkeye girmesine izin vermemiş ve diş dünya ile ilişkilerini minimum düzeyde tutmuştur. 1978 yılında uygulamaya konulan açık kapı politikasıyla birlikte yabancı yatırımların gelmesine olanak tanımış ve ihracatı teşvik etmiştir. 2001 yılına gelindiğinde Dünya Ticaret Örgütü (DTÖ) üyeliği ile birlikte Çin dış dünya ile ilişkilerini giderek arttırmaya başlamıştır. Değişimle birlikte büyüme ve zenginleșmenin yanı sıra liberalleşmenin yol açtığı dışsal şoklara maruz kalmaya da başlamıștır.

Bir ülkenin negatif şoklara karşı koyma gücü ekonomik dayanıklılığını, negatif şoklara karşı koyamaması ise ekonomik kırılganlığını göstermektedir. Ekonomik kırılganlık, mikro ve makroekonomik kırılganlık olarak tasnif edilirse şokların hane halkı refahı üzerindeki etkisine mikroekonomik kırılganlık, ekonomik büyüme üzerindeki etkisine ise makroekonomik kırılganlık denilmektedir.

$\mathrm{Bu}$ çalışmada, Çin ekonomisi için makroekonomik kırılganlık ile büyüme ilişkisi ekonometrik analizlerle araștırılmıştır. ADF testi sonucunda değişkenlerin birinci farkında durağan oldukları ve Johansen Eşbütünleşme testi sonucuna göre eş bütünleşik oldukları yani uzun dönemde birlikte hareket ettikleri tespit edilmiştir. Normalize edilmiş eş bütünleşme sonuçlarına göre de makroekonomik kırılganlığın büyümeyi pozitif olarak etkilediği kabul edilmiştir. İktisadi değişkenler arasındaki nedenselliğin yönü ise Granger nedensellik testi ile araştırılmıştır. Çin ekonomisinde büyümeden makroekonomik kırılganlığa, makroekonomik kırılganlıktan büyümeye doğru nedensellik ilişkisi mevcuttur. Kısaca, büyüme ile makroekonomik kırılganlık arasında çift yönlü nedensellik ilişkisi vardır. Çalışmada elde edilen sonucun Armstrong ve Read (2002), Dabla-Norris ve Gündüz (2014) ve Jimborean (2016)'nın bulgusuyla örtüşmesi araştırma bulgularını güçlendirmektedir. Ancak Lepers ve Serrano (2020), Briguglio vd. (2008), Gounder ve Saha (2007), Ren vd (2018) ve Fowowe ve Folarin (2019)'nın bulguları ile zitlık göstermektedir. Bu farklılığın Lepers ve Serrano (2020) ve Fowowe ve Folarin (2019)'nin finansal kırılganlığı değişken olarak seçmesinden, Briguglio vd. (2008)'nin farklı 
zaman aralı̆̆ını analiz etmesinden ve Gounder ve Saha (2007)'nın ise ada ülkelerini seçmesinden kaynaklandığı düşünülmektedir.

Sonuç olarak, Çin'in 1987-2018 yılları arasında büyüdügünü ve makroekonomik kırılganlığının da arttı̆̆ını söylemek mümkündür. Ülke en yüksek kırılganlığı küresel krizden hemen önce ve takip eden iki yılda yaşamıştır. MKE'nin 2011'den buyana yükselme trendinde olduğu da görülmüștür. Bu yükseliște en önemli rolü toplam diş borç/yıllık ihracat, toplam borç/GSYiH ve bankaların özel sektöre kullandırdığı yurt içi krediler/GSYIH göstergelerinin oynadığı düşünülmektedir.
Ancak son on yllda Çin ekonomisini krize sokacak bir kırılganlık düzeyi var olmamış ve yakın gelecekte de kırılganlığa bağlı bir kriz öngörülmemektedir. Enflasyon oranının yükselmemesi şartıyla, kırılganlık indeksini pozitif etkileyen cari fazla ve döviz rezervlerinin GSYiH'ye oranındaki azalışların durması kırılganlığı azaltacaktır. Buna ek olarak, indeksi negatif etkileyen dış borcun yılllk ihracata oranında, toplam borcun GSYiH'ye oranında ve bankaların özel sektöre kullandırdığı yurt içi kredilerin GSYIH'ye oranında artışların önlenmesi Çin ekonomisinin sürdürebilir büyümesine katkı sağlayacaktır.

\section{REFERANSLAR}

Aikman, D., Kiley, M.T., Lee, S.J. Michael G. Palumbo and Missaka N. Warusawitharana, (2015). "Finance and Economics Discussion Series Divisions Of Research, Statistics And Monetary Affairs Federal Reserve Board", Washington,D.C.,https://Www.Federalreserve. Gov/Econresdata/Feds/2015/Files/2015059p ap.Pdf, (16.12.2019).

Aldasoro, I.,Borio, C. Ve Drehmann, M. (2018). "Early Warning Indicators Of Banking Crises: Expanding The Family", Bis Quarterly Review , https://Www.Bis.Org/Publ/Qtrpdf/R Qt1803 e.Pdf, (12.12.2019).

Ansar,A.,Flyvbjerg, B., Budzier, A., Ve Lunn, D. (2016). "Does Infrastructure Investment Lead To Economic Growth Or Economic Fragility? Evidence From China" Oxford Review Of EconomicPolicy, 32(3), Pp. 360-390.

Armstrong, H. W. Ve Read, R. (2002). "The Phantom Of Liberty? Economic Growth And The Vulnerability Of Small States". Journal of International Development, 14(4), Pp. 435-458.

Atkins, J. Mazzi, S.,Easter C., (2000), ' A Commonwealth Vulnerability Index For Developing Countries: The Position Of Small States' Economic Paper No. 40, Commonwealth Secretariat, London.
Bayraktar, Y. Ve Elüstü, S. (2016). "Makroekonomik Kırılganlığın Ölçülmesi: Yükselen Piyasalar Ve Türkiye İçin Karşılaştırmalı Bir Analiz" Hak-İş Uluslararası Emek Ve Toplum Dergisi, 5(11), Ss. 9-29.

Briguglio, L. Cordina, G. Farrugia, N. Ve Vella, S. (2008). "Economic Vulnerability And Resilience Concepts and Measurements", Research Paper No. 2008/55, www.Wider.Unu.Edu/Sites/Default/Files/Rp2 008-55.Pdf, (15.12.2019).

Briguglio, L.VeGalea, W., (2003). “Updating And Augmenting The Economic Vulnerability Index", Occasional Paper By The Small States Institute,

https://Www.Researchgate.Net/Publication/2 39532719 Updating The Economic Vulnerabi lity İndex, (13.12.2019).

Borysko, S. (2017). "Early Warning Indicators Of The Crisis. Financial Vulnerabilities In Caucus And Central Asia", Berlin School of Economics And Law Master Of International Economics Ss2017, https://Www.HwrBerlin.De/Fileadmin/Portal/Dokumente/ProfSeiten/Metzger/Thesis 2017-

Borysko Sofia.Pdf, (14.12.2019).

Dalhaus, T. Ve Lam, A. (2018). "Assessing Vulnerabilities İn Emerging-Market 
Economies", Bank Of Canada Staff Discussion Paper 2018-13,

https://Www.Bankofcanada.Ca/Wp-

Content/Uploads/2018/10/Sdp2018-13.Pdf, (16.12.2019).

Elüstü, S. (2016). "Yükselen Piyasalarda Makroekonomik Kırılganlık Ve Türkiye Örneği, Yüksek Lisans Tezi, İstanbul Üniversitesi Sosyal Bilimler Enstitüsü İktisat Anabilim Dalı Teknoloji Ve Sanayi İktisadı, İstanbul.

Essers, D. (2015), “ Essays on Develophing Country Vulnerabilitiy to External Shocks in Light of the Great Ressesion", Universty of Antwerpen, 274s.

Fed (Federal ReserveSystem) (2014). "MonetaryPolicy Report", February 11, 2014 Washington, D.C.,July 15, 2014, https://Www.Federalreserve.Gov/Monetaryp olicy/Mpr Default.Htm, (20.12.2019).

Feenstra, R.C. Ve Wei, S.J. (2010). China's Growing Role In World Trade, Ed. : Robert C. Feenstra And Shang-Jin Wei, University of Chicago Press, Chicago, 603s.

Fowowe, B. ve Folarin, E.O. (2019). The Effects of Fragility and Financial Inequalities on Inclusive Growth in African Countries. Review of Development Economics. https://onlinelibrary.wiley.com/doi/epdf/10. $\underline{1111 / \text { rode. } 12594}$

Gounder, R. ve Saha, S. (2007). "Economic Volatility, Economic Vulnerability And Foreign Aid: Empirical Results For The South Pacific Island Nations", Department Of AppliedAnd International Economics DiscussionPaper No. $07.02 \quad$ March 2007 http://Econfin.Massey.Ac.Nz/School/Publicati ons/Discuss/Dp07-02.Pdf, (30.12.2019).

Guillaumont, P. (2011). "Macro Vulnerability In LowIncome Countries And Aid Responses", Hal Id: Halshs-00570499.

Gujurati, D.N. (2001). Temel Ekonometri, Çev. : Gülay G. Şenesen Ve Ümit Şenesen, Literatür Yayınları, İstanbul, 849s.
Hermansen, M. Ve Rohn, O.,(2015). "Economic Resilience: The Usefulness Of Early Warning Indicators In OECD Countries", Economics Department Working Papers No. 1250 DOI: 10.1787/5jrxhgfqx3mv-En

IMF, (2003), "External Debt Statistics : Guide For Compilers And Users" https://Www.Imf.Org/External/Pubs/Ft/Eds/ Eng/Guide/File4.Pdf, (15.12.2019).

IMF, (2008). "Vulnerability Indicators", https://www.Imf.Org/External/Np/Exr/Facts /Vul.Htm (18.12.2019).

IMF, (2019).

Https://Www.İmf.Org/External/İndex.Htm,

(16.12.2019).

Jimborean, R. (2018). "What Drives Private Non-Financial Sector Borrowing In Emerging Market Economies?", Economics And Statistics Institut National De La Statistique Et Des Études Économiques, 503-504, Pp. 143-161. Https://Doi.Org/10.24187/Ecostat.2018.503d. $1962,(13.12 .2019)$.

Kaplan, F. Ve Yapraklı, S. (2014). "Ekonomik Kırılganlık Endeksi Göstergelerinin Döviz Kuru Üzerindeki Etkileri:Kırılgan 12 Ülke Üzerine Panel Veri Analizi" , Uluslararası Alanya İșletme Fakültesi Dergisi, 6(3), Ss. 111-121.

Karakurt, B. H. Şentürk Ve Ela M., (2015). "Makroekonomik Kırılganlık: Türkiye Ve Şangay Beşlisi Karşılaştırması", Yönetim Ve Ekonomi Araştırmaları Dergisi, 13(1), Ss. 283307.

Kidochukwu, O. (2015). "IMF Recommended Debt Sustainability Threshold for Nigeria. Is It Growth Augmenting? An Optimization Algorithm Approach", OIDA International Journal of Sustainable Development, Vol. 08, No. 11, pp. 81-90 SSRN: https://ssrn.com/abstract=2709119 (3.7.2020).

Lepers, E. Ve Serranob, A.S., (2018). Decomposing Financial (In) Stability In Emerging Economies", Elsevier, 51, January 2020, 101068 
Mansor, S.A. , Puah, C.H., Liew, V.K. Ve Wong, S.S., (2015). "An Early Warning Indicator of Economic Vulnerability Constructing For Malaysian Economy", Economics And Management Of National Economy, 3-4(1), Pp. 37-41.

Melville J. Ve Brathwaite, J. (2006). "Revised Economic Vulnerability Index 2002", https://Www.Centralbank.Org.Bb/News/Artic le/6630/Revised-Economic-Vulnerabilityİndex-2002, (12.12.2019).

Minsky, H. P. (1976). A Theory Of Systemic Fragility, https://Digitalcommons.Bard.Edu/Hm Archiv e/231/, (30.12.2019).

Minsky, H. P. (1995). "Sources Of Financial Fragility: Financial Factors İn TheEconomics Of Capitalism",

Https://Digitalcommons.Bard.Edu/Cgi/Viewc ontent.Cgi?Article $=1068 \&$ Context $=\mathrm{Hm}$

Mulder, C. Ve Bussière, M., (1999). "Political Instability And Economic Vulnerability", IMF Working Paper , 1999(46), Pp. 1-36.

Naude, W.,Paulino, A.U. ve Mcgillivray, M. (2009). "Vulnerability İn Developing Countries: An Introduction, Research Brief", Https://Collections.Unu.Edu/Eserv/Unu:3076 /Rb02 08.Pdf (14.12.2019).

NBSC, (NationalBureau Of Statistics Of China) (2019),

Http://Www.Stats.Gov.Cn/Tjsj/Ndsj/2018/İn dexeh.Htm

Neely, C. J., (2017). “Chinese Foreign Exchange Reserves, Policy Choices And The U.S. Economy", WorkingPaper 2017-001a, https://Papers.Ssrn.Com/Sol3/Papers.Cfm?Ab stract İd=2952262, (12.12.2019).

Norris E. D. ve Gündüz, B. Y., (2014). "Exogenous Shocks and Growth Crises In LowIncome Countries: A Vulnerability Index", World Development, 59, Pp. 360-378.

OECD, (2008). "Handbook On Constructing Composite Indicators: MethodologyAnd User Guide"
Http://Www.Oecd.Org/Sdd/42495745.Pdf, (15.12.2019).

Örnek, İ. (2008). "Yabanci Sermaye Akımlarının Yurtiçi Tasarruf ve Ekonomik Büyüme Üzerine Etkisi: Türkiye Örneği", Ankara Üniversitesi Sbf Dergisi, 63 (02), Ss. 199-217.

Özyıldız, H. (2019). "Kırılganlık Göstergeleri" Http://Www.Hakanozyildiz.Com/2014/02/Kr lganlk-Gostergeleri.Html (11.12.2019).

Petek, A. ve Çelik, A. (2017). “Türkiye'de Enflasyon, Döviz Kuru, İhracat ve İthalat Arasındaki İlişkinin Ekonometrik Analizi (1990-2015)", Finans Politik İle Ekonomik Yorumlar, 54( 626), Ss. 69-87.

Ren, C., Zhal, G., Zhou, S., Chen, W., veLi, S. (2018). "A Comprehensive Assessment And Spatial Analysis of Vulnerability of China's Provincial Economies", Sustainability 2018, 10, 1261; DOI:10.3390/Su10041261

Seth, A. ve Ragab, A. (2012). "Macroeconomic Vulnerability In Developing Countries: Approaches And Issues," Working Papers 94, International Policy Centre For Inclusive Growth,

https://Ipcig.Org/Pub/Ipcworkingpaper94.Pd $\mathrm{f},(13.12 .2019)$.

Sun, L., (2015). “China's Debt: Structure, Determinants And Sustainability", Https://Mpra.Ub.Uni-

Muenchen.De/68548/1/Mpra Paper 68548.P df (12.12.2019).

Supriyadi, A. (2014). "External Vulnerability Indicators: The Case of Indonesia", Https://Www.Bis.Org/Iff/Events/7ifcconf Su priyadi.Pdf, (13.12.2019).

Tarl, R. ve Bozkurt, H. (2006). “Türkiye'de İstikrarsız Büyümenin Var Modelleri İle Analizi (1991.1-2004.3)", İstanbul Üniversitesi İktisat Fakültesi Ekonometri ve İstatistik Dergisi , Ekonometri ve İstatistik Sayı :4 Ss. 12-28.

Tokucu, E. (2012). “Hyman Minsky'nin Finansal İstikrarsızlık Hipotezi Çerçevesinde Finansal Krizler ve Çözüm Önerileri”, Sbf Dergisi, 67(2), Ss. 189-212. 


\section{BAYLAN}

UNCTAD, (1997). "The Vulnerability Of Small Island Developing States İ The Context Of Globalisation: Common Issues And Remedies", Report Prepared For The Export Group On Vulnerability Index. Un Desa, Https://Unctad.Org/En/Pages/Home.Aspx, (14.12.2019).

Wang, Y. (2006). China As A World Factory "Cheap Labor And China's Export Capacity", Taylor And Francis, Londra, Ed. Kevin H. Zhang, $14 \mathrm{~s}$.

Wells, J. (1997), “Composite Vulnerability Index: A Revised Report", Report For The
Commonwealth Secretariat Consultative Group On Small States, Faculty Of Economics And Politics, University Of Cambridge, Cambridge, August 1997

World Bank, (2019). Https://Databank.Worldbank.Org/Source/Wo rld-Development-İndicators, (16.12.2019).

Yuanchun, L.,(2015). Managing Inflation In China Current Trends And New Strategies, Enrich Professional Publishing, Hong Kong, 234s. 